\title{
WASTE MANAGEMENT IN DEVELOPED AND DEVELOPING COUNTRIES: THE CASE STUDY OF UMBRIA (ITALY) AND THE WEST BANK (PALESTINE)
}

\author{
Francesco Di Maria ${ }^{*, 1,2}$, Elena Lovat ${ }^{3}$ and Marco Caniato ${ }^{3}$ \\ ${ }^{1}$ LAR5 Laboratory, Dipartimento di Ingegneria, University of Perugia, via G. Duranti 93, 06125, Perugia, Italy \\ ${ }^{2}$ CIMIS Consortium, via G. Duranti 67, 06125, Perugia, Italy \\ ${ }^{3}$ Cesvi, via Broseta 68a, 24128, Bergamo, Italy
}

Article Info:

Received:

17 January 2018

Revised:

16 June 2018

Accepted:

30 July 2018

Available online:

27 August 2018

Keywords:

Developing countries

Waste managment

EU area

West bank

\begin{abstract}
A survey and a preliminary comparison were conducted between the waste management systems and schemes implemented in the Region of Umbria (Italy) and the West Bank (Palestine). The Region of Umbria operates in a wider political legal and economic supporting scheme, i.e., the one promoted by EU Directives. The West Bank showed all the typical economic, legal and political features of a developing country. From the economic point of view the incidence of the cost for waste collection and management with respect to the per capita GDP was $0.82 \%$ for the Region of Umbria and $1.2 \%$ for the West Bank. Although the incidence for the West Bank was higher, it was not enough to support the budget necessary for efficient waste management. A relevant aspect was the practically similar amount of organic waste generated per capita and per year in the two areas. The West Bank lacks infrastructures and adequate collection systems and there are no composting facilities. The number of mechanical sorting facilities was $0.034 / 10^{5}$ inhabitants. The current recycling rate for the West Bank is about $6 \%$. Some criticism about the sustainability of recycling and composting rates for the Region of Umbria are also highlighted. Some benefits for the West Bank, such as the introduction of home composting, are identified. This will affect both the amount and the costs of waste collected allowing the municipalities to allocate more money for separated collection of recyclables.
\end{abstract}

\section{INTRODUCTION}

Although having different perspectives, waste management is one of the key issues to be addressed both by developed and developing countries for achieving a sustainable implementation of the various human activities worldwide.

According to Marshall and Farahbakhsh (2013), progress in the waste management sector has been historically influenced by six key factors: public health; environment, resource scarcity, waste value, climate change and public awareness. These aspects are affected both directly, as by the emissions generated from incorrect collection and disposal of wastes (Couth and trois, 2011, 2012; Tian et al., 2013), and indirectly as a consequence of raw materials consumption and transformations (Di Maria et al. 2014).

Currently the most effective approach for waste management worldwide is based on the three R concept: Reuse, Recycle and Recovery. This was extrapolated from the wider concept of the waste management hierarchy, introduced in the European Union (EU) in 1977 by the European Com- mission (CEC, 1977), stating the main activities and goals to be pursued with strict hierarchic order in waste management: Prevention; reuse; recycle; recovery; disposal.

The hierarchy concept was definitively introduced in the EU legislation, becoming a fundamental component of the integrated waste management approach in the EU in 1991 by the first Directive 91/156/EEC on waste (Council Directive, 1991). This has always been confirmed throughout the years including the latest Waste Framework Directive (WFD, 2008) that introduced another important goal to be achieved within 2020 by member states: the recycling of at least of $50 \%$ of the whole waste generated. Recycling also includes the organic fraction via biological treatments that is able to generate organic fertilizer, effectively exploitable in agriculture.

Furthermore, the implementation of the waste management hierarchy was described by the European Commission (EC) as a key activity in communication n ${ }^{\circ} 614$ (COM, 2015) concerning the EU Action Plan on circular economy. A key factor for the optimization of recycling and reuse is 
effective and efficient waste collection, consisting of efficient source segregation able to return high quality recyclables directly exploitable in industry. Municipalities are the authorities in charge of providing municipal solid waste (MSW) collection directly or by private/public companies. Currently, collection coverage in the EU15 is practically $100 \%$.

For the year 2016 the MSW management in the EU15 was: gross generation 207,862,000 Mg; Recycling 29.5\%; Composting and /or anaerobic digestion (AD) $17.4 \%$; Incineration 29.9\%; Landfilled (sanitary landfills) $23.1 \%$. Considering that the percentage of bio-waste in the municipal solid waste (MSW) at the EU15 level is about 30\%, more than $50 \%$ is currently recycled by composting or integrated processing with $A D$ and post-composting (Di Maria et al. 2016; Smidt et al., 2011). The remaining amount could be considered quite equally shared between the amount of waste incinerated and the amount landfilled.

Waste management in most developing countries is still greatly based on uncontrolled dumping and/or littering and, domestic burning. This mismanagement leads to serious health and environmental problems (Guerrero et al., 2013; Henry et al., 2006; Sharholy et al., 2008; Al-Khatib et al., 2010). Kumar et al. (2009) showed that more than $90 \%$ of MSW in India is directly disposed of on the land in an unsatisfactory manner and collection coverage is often less than 60\% (Zhang et al., 2010; Henry et al., 2006). Couth et al. (2011) reported that in Africa GHG emissions from waste management were 3 times higher than those in developed countries and similar results were also reported by Tian et al. (2013) concerning the Chinese scenario. Per capita production ranges from $0.4 \mathrm{~kg} /$ day to $1.0 \mathrm{~kg} /$ day (Zhang et al., 2010), peaking in certain areas also up to 1.7 $\mathrm{kg} /$ day (Manaf et al., 2009). The organic fraction content ranges from $45 \%$ up to more than $80 \%$ of the whole waste generated in developing countries, representing the main source of health and environmental concerns (Al-Khatib et al., 2010; Zhang et al., 2010; Henry et al., 2006;). In general, the waste management system consists in transporting the waste outside of cities (Marshall et al., 2013). The rapid and unplanned growth of cities has led to extreme land use problems and infrastructural challenges that have crippled the capacity of governments and local authorities to increase MSW services to meet the demands (Marshall et al., 2013). Funding and technical competency to provide an efficient waste collection service are lacking (Al-Khatib et al., 2008; Henry et al., 2006). Similarly, Guerrerio et al. (2013) confirmed that waste management failure in cities of developing countries is due to inadequate technical, environmental, financial, socio-cultural, institutional and legal aspects. A study showed that political instability, civil wars and military operations contribute to increasing the difficulties in the waste management sector. From the social point of view the extraction of recyclables from waste is largely performed by the informal sector often operating in unsafe conditions (Manaf et al., 2009). In general recycling figures were very poor, less than $10 \%$, together with a significant lack of facilities for the treatment of the largest and most threatening waste component, the organic fraction (Kumar et al., 2009). Concerning Palestine and the West Bank area, the waste generation ranges from $0.48 \mathrm{~kg}$ per person per day up to $2.00 \mathrm{~kg} / \mathrm{per} /$ day. Despite the high coverage (98\%), more than $80 \%$ of the waste is open dumped. It is also reported that from $2 \%$ to $8 \%$ of the municipal budget is dedicated to MSW management (MSWM), indicating a low priority for this activity (Al-Khatib et al. 2007). As reported by Khatib et al. (2010) for the Nablus district the percentage of the organic fraction in the MSW was about 65\%, whereas the annual fee for MSWM was about 51 USD/year.

The aim of the present work was to assess the waste management status in the Region of Umbria (Italy) and in the West Bank (Palestine), in order to quantify some social and waste management indicators able to give a more objective assessment of the problems in the two areas.

\section{MATERIAL AND METHODS}

\subsection{Study area}

The present study was carried out in the Region of Umbria (Italy) (Figure 1a) and the West Bank (Figure 1b) (Palestine). The Region of Umbria consists of about 900,000 inhabitants with a total surface area of about $8,500 \mathrm{~km}^{2}$ characterized by the presence of large mountainous areas and temperate climatic conditions. The average per capita GDP in 2012 was about 23,00 €. The West Bank consists of about $3,200,000$ inhabitants on a total surface area of about $5,640 \mathrm{~km}^{2}$ with arid climatic conditions. The per capita GDP for 2014 was about 4,300 USD (CIA, 2017). The study was conducted following these main methods.

\subsection{Data collection and waste management assess- ment components}

An in-depth analysis was carried out of the available literature and the annual reports from national and local authorities addressing the waste management implementation status. Available reports and documents about waste management in Palestine, including relevant regulations together with direct experiences of the authors operating in that area were reviewed Cesvi NGO. For the Region of Umbria both lab scale and full scale studies were performed at some of the plants (Di Maria et al., 2016; Di Maria et al., 2015; Di Maria, 2012) as well as on the basis of waste management reports of national authorities (ISPRA, 2016). Field visits and the technical/scientific analysis of facilities and waste management service providers, recycling companies, landfills, relevant facilities and stakeholders were done.

This was also performed for the Region of Umbria (Figure 1a) through a project funded by EC grant LIF12 IT/ ENV/000411 from 2014 to 2016.

The study involved many stakeholders, mainly the University of Perugia, the Region of Umbria, local governments, one municipality and two main waste management companies managing the collection system and the different facilities operating in the area considered, such as mechanical biological treatment (MBT), composting and landfill. For Palestine (Figure 1b) this was performed by Cesvi NGO, also financed by the United Nations as part of the UNRWA project (2017). During this project citizens, municipalities and waste management companies were in- 


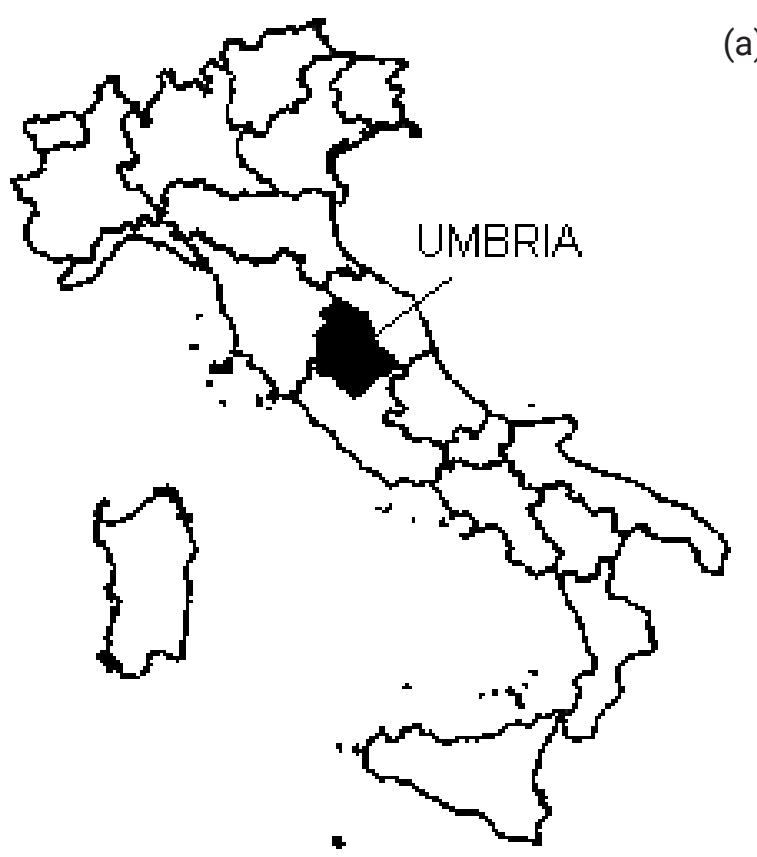

(a)

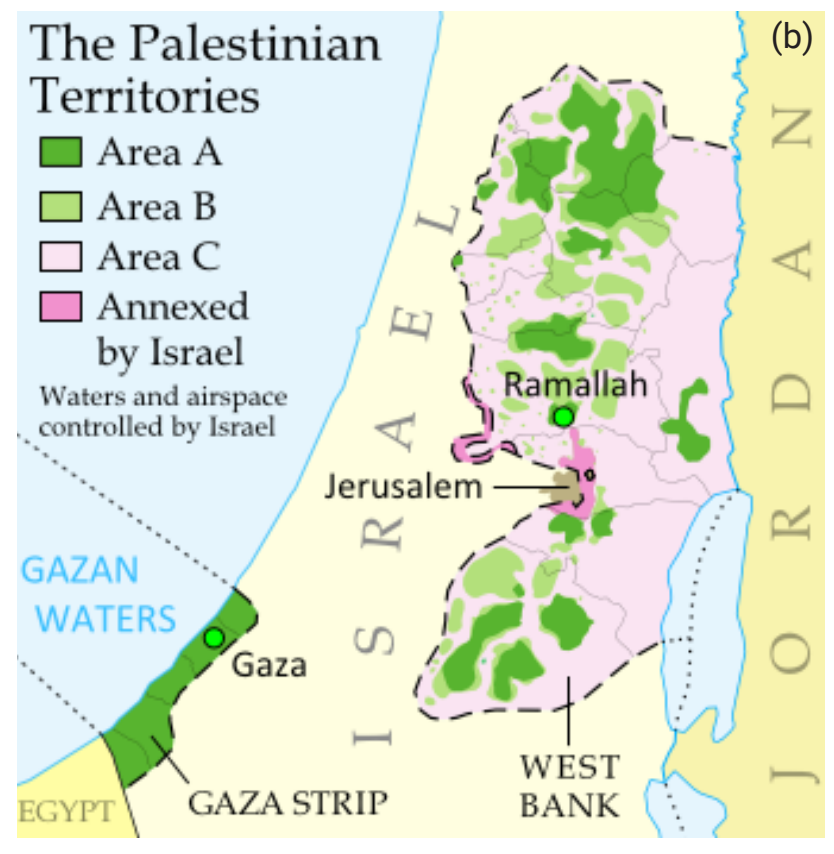

FIGURE 1: Location of the study area: (a) the Region of Umbria, and (b) the West Bank (dashed) (b) (Centanni, 2012).

volved in defining a strategic waste management plan for 2018-2023 in those areas.

These stakeholders were also directly interviewed to assess the attitude regarding waste separation, the efficiency of the collection system and the objective to be pursued.

\subsection{Data analysis and study limitations}

The analysis and comparison of the two areas were conducted according to the following main indicators: per capita MSW generated; per capita organic fraction generated; percentage of waste management fee/per capita GDP (\%); number of mechanical treatment facilities per $10^{5}$ inhabitants; number of composting facilities per $10^{5}$ inhabitants; recycling percentage (\%); composting percentage (\%).

These indicators will give an assessment about; the current level of waste management implementation; socio-economic correlations; waste management efficiency related to material recovery and recycling; effective implementation of a waste management strategy.

In particular the incidence of the waste management fee on the per capita GDP will provide information about the relative economic sustainability of the MSWM and also about the socio- economic incidence on the efficiency of this activity. The number of treatment facilities per inhabitant is another important aspect assessing the presence of specific goals and infrastructure in the sector. Similarly composting and recycling percentages indicate the efficiency and the presence of specific goals in managing one of the largest MSW components.

The study is mainly aimed at quantifying some relevant differences and/or similarities in the two areas under investigation using the indicators defined above. This could lead to an objective evaluation of criticisms and of current performances, also highlighting some causes of low efficiencies.

\section{RESULTS}

\subsection{The region of Umbria}

\subsubsection{Status of waste production and management}

The amount of MSW generated in 2015 was $519 \mathrm{~kg} / \mathrm{per}$ capita, $48.9 \%$ of which was collected separately at source (ISPRA, 2016). Except for the organic fraction and greens, different wastes separated at source are moved to the recycling industry directly or via specific national consortiums. National consortiums were imposed at the time of the first EU Directive 91/156/EEC on waste management for implementing the extended producer responsibility (EPR). In contrast, the organic fraction and greens from separate collection are processed in 5 biological treatment facilities operating at the regional scale and managed by waste collection and/or treatment companies for the production of an organic fertilizer in compliance with the Italian legislation (D.Lgs., 2010). Of these 5 facilities 4 are exclusively aerobic, whereas 1 consists of integrated anaerobic pre-treatment followed by a post composting phase.

According to the EU and National legislation, MSW coming from the separated collection has to be properly processed before being disposed of in landfill. These treatments are aimed to extract other recyclables and or recoverable materials from the residual wastes, including energy recovery, and to reduce their final biological reactivity. As indicated by the first EU Directive 91/156/EEC, the most suitable treatment is by incineration which is able to recovery energy and, most importantly, to reduce both the mass and the reactivity of the materials, mainly returned slags. As an alternative to incineration, even if with lower efficiency in mass and reactivity reduction, MBT was wide- 
ly adopted mainly due to its lower costs.

Currently in the Region of Umbria, there are $3 \mathrm{MBT}$ in operation and one mechanical sorting (MS) facility processing about 222,000 Mg/year (2015) of residual MSW. There is no incineration facility for MSW.

The amount of waste disposed of in the 3 sanitary landfills was estimated at 260,000 Mg/year in 2015.

According to national and European legislation, municipalities are charged with collecting MSW. They can operate on their own or they can entrust it to private companies after public calls. The most widespread option is by private companies participating usually not less than $50 \%$ by municipalities. The MSW fee includes the whole service from collection, to recycling and disposal. According to the recycling goal imposed by the EU (WFD, 2008) the current MSWM is strongly oriented at improving recycling.

\subsubsection{Separated collection}

Separated collection at source has been demonstrated to be the most efficient method for returning high quality materials suitable for high recycling efficiency. This collection methodology is practically implemented in the entire regional area.

Two main methods are currently used to achieve this aim:

- Door-to-door collection;

- Proximity collection.

Together with these two methods there is also a large use of city amenities.

A timetable appositely developed is delivered each year to users indicating the collection frequency for each waste material. The organic fraction is collected 2 to 3 times per week, whereas, the other fractions are collected every 2 to 4 weeks. Glass is collected only by the proximity method.

Currently, 43 city amenities are in operation in the regional collection, separating the following waste streams: plastics; glass; electric and electronic wastes (WEEE); plant and animal oils; paper, cardboard and multi-layer; lubricating; gardening; bulky and others.

Regarding debris from small households, only small quantities up to $150 \mathrm{~kg}$ per year per user are allowed. Higher amounts are classified as special waste and have to be delivered to specific recycling/disposal plants. Users who deliver wastes to the amenities are credited by economic incentives, depending both on the amount and type of waste. Furthermore, city amenities play an important role regarding the amount of waste collected separately. More than $40 \%$ of the waste collected separately arises from these facilities. With respect to 2015 the entire management of one tonne of waste cost on average $190.8 € /$ tonne. Some innovation was introduced in this region by the economic support of a LIFE project EMaRES (Grant $n^{\circ}$ LFE12 ENV/IT/000411). Three main innovations were introduced to demonstrate their effectiveness:

- The first was the introduction of a traceability system based on bar codes and chips for door-to-door collection. With this system it was possible to know exactly the user, the amount of waste returned and the quality. Operators had to verify the quality of waste returned and to warn citizens if they were not operating correctly. On the other hand, this system was useful for user awareness and for implementing a pay-as-you-throw (PYT) fee system;

- The second was the implementation of a dynamic collection center for increasing the amount of small electric waste and electronic equipment WEEE (mobile phones, remote controller, hair drier...), used cooking oil and batteries returned by the citizens (Figure 2). In practice this was an appositely equipped truck able to move to the citizens, according to a specific timetable, in the various places of their everyday life, such as supermarkets, shopping centers, fairs, events. This vehicle also plays an important role in the continuous awareness of the population;

- The third was the implementation of an advanced me-

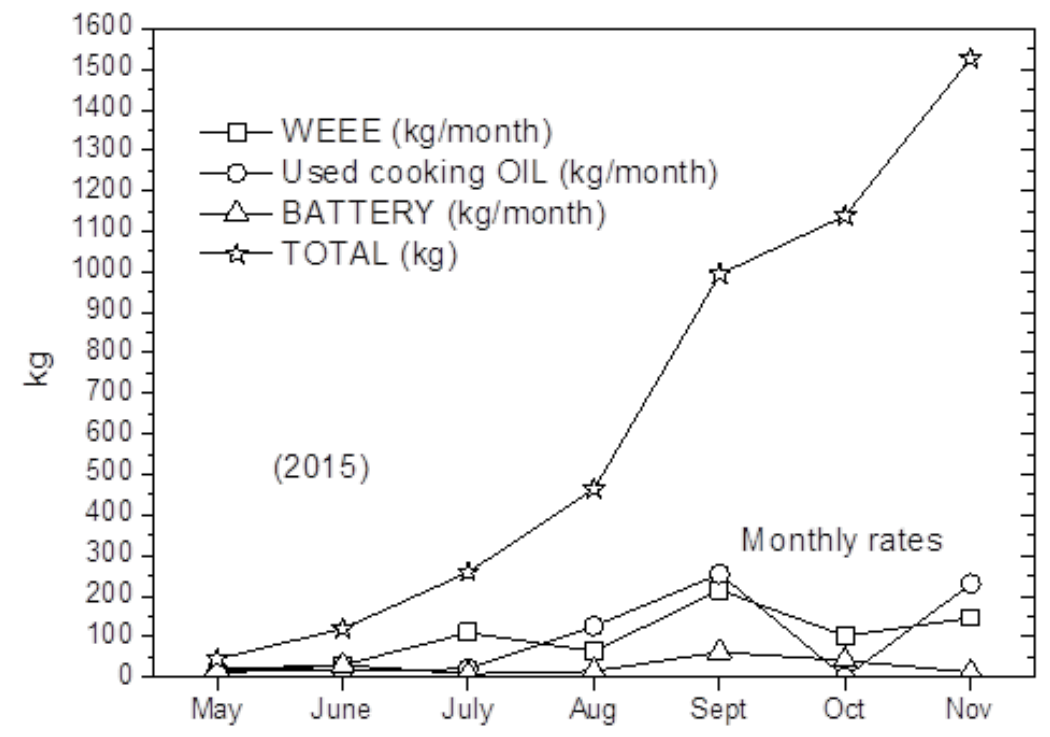

FIGURE 2: Amount of specific waste collected by the mobile collection center during its first months of operation. 
chanical treatment system for the extraction of further recyclable materials from residual waste. This plant was equipped with different mechanical, physical and optical selectors and it was able to return on average from $9 \%$ to $10 \%$ of recyclables (plastics, metals and glass) from the residual waste (Di Maria et al. 2015).

\subsubsection{Recycling}

Waste delivered for recycling comes mainly from the separated collection. In 2015 the amount of waste material collected separately and moved to recycling was globally about 221,000 (Mg/year) (Table 1). The largest fractions were organic, paper, glass and plastic.

These materials were successively delivered to the national consortiums for recycling. The main national consortiums were CdC RAEE for WEEE and CONAI for packaging in plastics, paper, aluminium, steel, wood and glass. CONAI includes specific consortiums: CoReVe for glass packaging; CIAL for aluminium; RICREA for steel; COMIECO for paper and cardboard; RILEGNO for wood; COREPLA for plastics. In some cases, collection companies directly deliver the waste to the recycling industry.

\subsubsection{Composting and anaerobic digestion}

In the Region of Umbria there are five biological treatments for processing the organic fraction returned by separated collection. The achievement of end of waste criteria for this material is defined by the national legislation which imposes specific conditions on the waste source, on the process performances and on the features of the final product. For recycling, waste has to be the organic fraction separated at source (kitchen waste, green waste, restaurant). The process has to respect the following requirements: aerobic; lasting for not less than 90 days; able to guarantee $55^{\circ} \mathrm{C}$ for not less than 3 days (pathogen removal). Quality standards for final products are imposed by the Italian legislation for organic fertilizer (D.Lgs., 2010) (Table 2).

Currently Italian and EU legislation lacks specific criteria concerning recycling of the organic fraction by anaerobic digestion (AD). Consequently this limits the implementation of this technology in the specific sector.

At the regional level there is only one integrated $A D$ and post-composting plant, which in 2015 processed 34,402 $\mathrm{Mg} /$ year of organic fraction from separated collection generating $3,810,431 \mathrm{Nm} 3$ of biogas and 5,166 MWh of electrical energy. The amount of organic fertilizer generated in 2015 was 2,999 Mg. This means that the average biogas yield per single tonne was about $111 \mathrm{Nm}^{3} / \mathrm{Mg}$, whereas the specific energy recovery was about $150 \mathrm{kWh} / \mathrm{Mg}$. Sustainability of the higher investment and maintenance costs for $A D$ was supported by economic incentives for the cost of electricity recovered accessible by new facilities until 2013. After that date, the only possible incentive achievable by $A D$ was the generation of bio-methane. Currently a new $A D$ facility for organic waste aimed at bio-methane generation is under construction in the Region of Umbria. Globally the amount of organic fraction processed in these 5 facilities in 2015 was $180,432 \mathrm{Mg}$ with the production of $8,878 \mathrm{Mg}$ of organic fertilizer.

\subsubsection{Mechanical biological treatment}

Currently three MBT are in operation (Figure 3) and are able to sort the MSW into two main streams, a dry stream rich mainly in plastics, paper, cardboard and textiles, and a wet stream rich mainly in the organic fraction, together with metals (both ferrous and aluminium) for extraction and recycling. For these facilities the wet stream is then successively processed in an aerobic bio-stabilization section (Di Maria, 2012).

Together with these three MBT, there is a mechanical sorting (MS) facility returning a dry, a wet and a recyclable stream (metals). For these three MBT the mass balances for 2015 were: Inlet: 165,771 Mg of MSW; Outlet: 123,877 $\mathrm{Mg}$ of dry fraction to landfill; Outlet: $45,034 \mathrm{Mg}$ biostabilized wet fraction to landfill; Outlet: $708 \mathrm{Mg}$ of ferrous metals to recycling; Outlet: $35 \mathrm{Mg}$ of aluminium to recycling. For the MS the mass balance for 2015 was: Inlet: 48,629 Mg of MSW; Outlet: $27,212 \mathrm{Mg}$ of dry fraction to landfill; Outlet: $19,650 \mathrm{Mg}$ of wet fraction to landfill; Outlet: $85 \mathrm{Mg}$ of ferrous metals to recycling. The energetic consumption for MBT was on average $30 \mathrm{kWh} / \mathrm{Mg}$, whereas the MS facility had an average consumption of $17 \mathrm{kWh} / \mathrm{Mg}$ (Di Maria, 2012; Di Maria et al., 2015).

According to national and EU legislation, the wet fraction returned by MBT has to be adequately bio-stabilized

TABLE 1: Amount of waste materials moved to recycling in the year 2015 .

\begin{tabular}{l|c} 
Material & Amount (Mg/year) \\
\hline Organic fraction and green & 104,500 \\
\hline Paper & 54,800 \\
\hline Glass & 26,900 \\
\hline Plastic & 17,965 \\
\hline Metals & 5,143 \\
\hline Wood & 8,220 \\
\hline WEEE & 4,090 \\
\hdashline Textile & 1,680 \\
\hline Other & 3,200 \\
\hline
\end{tabular}

TABLE 2: Mean chemical and physical features required by Italian legislation for classifying compost from bio-waste as organic fertilizer.

\begin{tabular}{l|c|c}
\hline Parameter & Value & u.m. \\
\hline Moisture Content & $<50$ & $\% \mathrm{w} / \mathrm{w}$ \\
\hline $\mathrm{pH}$ & $6.0-8.5$ & - \\
\hline $\mathrm{TOC}$ & $>20$ & $\%$ on TS \\
\hline TKN & - & $\%$ on TS \\
\hline $\mathrm{N}$ organic & $>80 \%$ of TKN & $\%$ on TS \\
\hline $\mathrm{C} / \mathrm{N}$ & $<25$ & - \\
\hline $\mathrm{Cu}$ & $<150$ & $\mathrm{ppm}$ on TS \\
\hline $\mathrm{Zn}$ & $<500$ & ppm on TS \\
\hline $\mathrm{Pb}$ & $<140$ & ppm on TS \\
\hline Germination Index & $>60$ & $\%$ \\
\hline
\end{tabular}

Legend: TKN=Total Kjeldahl Nitrogen / TOC=Total Organic Carbon 

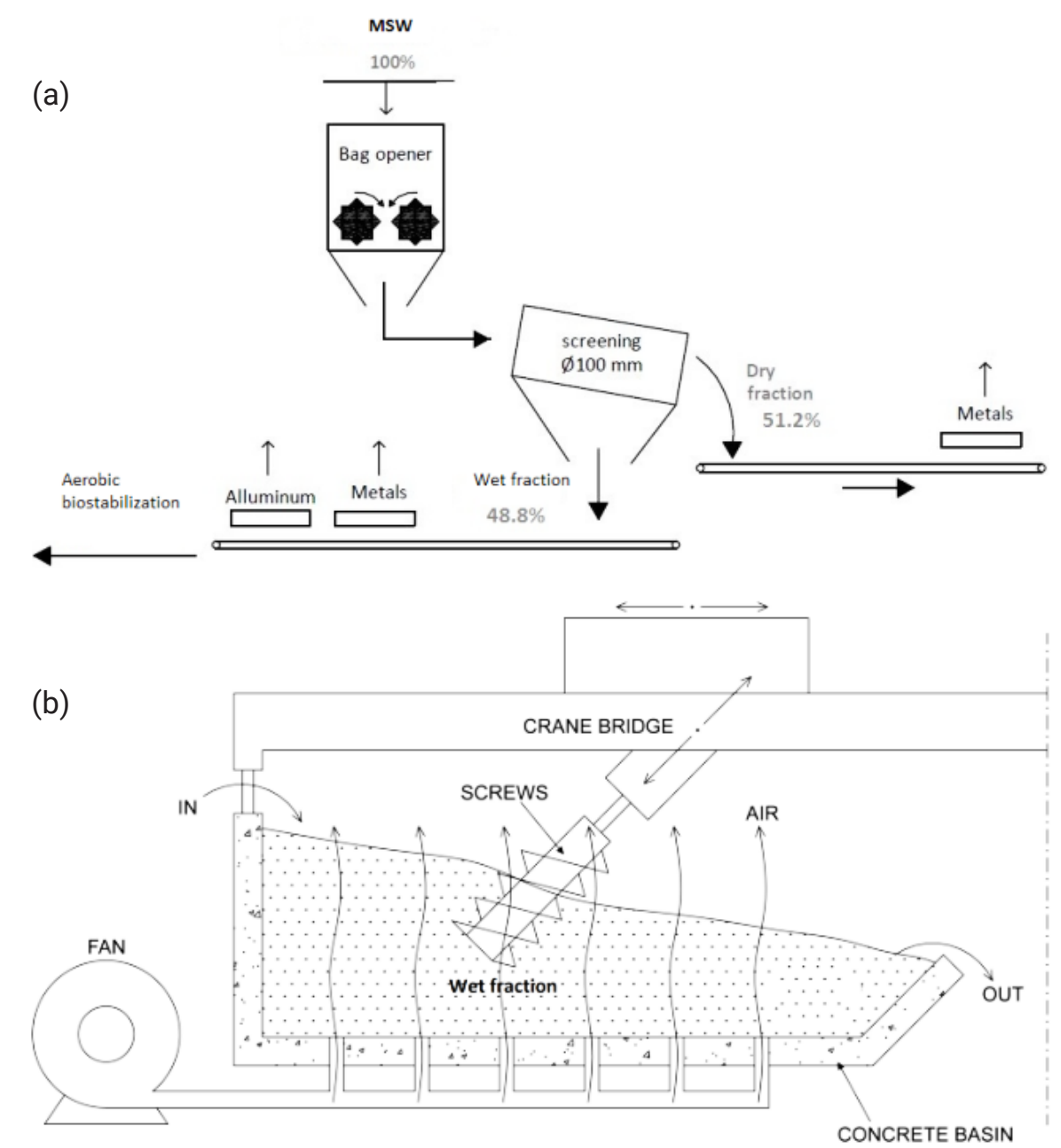

FIGURE 3: Scheme of the MBT sections: (a) mechanical sorting (MS) and (b) bio-stabilization.

for reducing the amount and the intensity of emissions during landfilling. The quality of the waste, particularly the wet fraction, is evaluated by a standardized methodology based on the dynamic respiration index (DRI) (mgO2/ kgVs*h) (Di Maria and Micale, 2014). The DRI threshold imposed by national legislation for acceptance in landfill is $\mathrm{DRI} \leq 1,000$ ( $\mathrm{mgO} / \mathrm{kgVS}$ h) and even more stringent limits are imposed at the regional level. Several studies performed in similar geographical areas such as Italy and EU Member States (De Gioannis et al., 2009; Komilis et al., 1999) and in a specific geographical area (Di Maria et al., 2013) indicate a reduction in gaseous emissions of landfilled waste after bio-stabilization of up to $90 \%$ when compared to untreated waste.

\subsubsection{Landfill}

The amount of waste landfilled in 2015 was globally 264,504 Mg consisting of the following fractions: 12,531 Mg of MSW directly landfilled without any pre-treatment; $230,929 \mathrm{Mg}$ of waste landfilled after treatment (MBT or MS); $21,062 \mathrm{Mg}$ of waste different from MSW (commercial activities).

All the landfills currently operating are sanitary landfills equipped with landfill gas collection, energy recovery and a leachate collection system. Leachate treatment is performed both on site and off site (Di Maria and Sisani, 2017; Di Maria et al, 2018; Morello et al., 2016; Spagni et al., 2008).

\subsection{West Bank}

\subsubsection{Status of waste production and management}

According to ARIJ (2015), the total solid waste generated in 2015 was $0.78 \mathrm{Mg} /$ day, - composed of $45-50 \%$ of household waste, $20-25 \%$ of construction and demolition waste and industrial waste, while the remaining amount was generated by commercial and institutional facilities. In $2015,95 \%$ of households were reportedly served by a service provider, while $85 \%$ paid collection fees. Only $50 \%$ of the waste produced was landfilled, and the recycling rate was only $6 \%$. However, these values are only estimates, and may be disputable, as indicated by Cesvi assessment activities in the sector.

A set of laws and policies regulate the solid waste management sector - including the National Strategy for Solid Waste Management 2010-2014 (MoLG, 2010), extended to 2017 and soon to be replaced. However, the legal and regulatory framework still looks incomplete and requires additional and more ready-to-implement laws and regulations. 
The population of the West Bank was served by three different types of service providers. These actors were municipalities, the Joint Service Councils (JSC) for waste management and the United Nations Relief and Works Agency for Palestine Refugees in the Near East (UNRWA). Municipalities are the local authorities responsible for the service, and may decide to directly implement it or to contract a company working on its behalf. Few options are available as part of the MSW management (MSWM) service contracted out, especially to private companies, for example cardboard collection in the Tulkarem governorate. Instead, it is more frequent that municipalities of the same governorate join a publicly-owned company which replaces the municipalities for all the MSW steps required or for haulage and disposal, only. Finally, UNRWA provides refugees living in the 19 camps of the West Bank with various services, including MSWM.

Despite a certain number of recycling activities available - mainly informal - the number of MSWM facilities is limited. Three sanitary landfills - in Zharat al Finjan in the North, one in Al Minya in the South and a small one in Jericho in the East - are the only available disposal sites, apart from a large number of small and medium dumpsites, still used by small municipalities. There is a large private transfer station in Eizeriya which mainly serves the area of Israeli settlements. Waste collected in this transfer station is sent either to the Al Minya landfill - near Bethlehem - or to the Atarot sorting plant - in Israel, if it comes from Palestinian towns and villages or Israeli settlements, respectively. Small transfer stations are owned and managed by private enterprises, municipalities, and JSCs, mainly for local use. The environmental performances of the listed facilities are scarce, and all of them require immediate interventions.

There are at least, ten composting plants in the West Bank, owned by private companies or cooperatives. Some of them are grouped by the Agricultural Development Association, which provides them with some support and services. However, some of them are currently closed due to unsustainable management costs and difficulties in properly commercializing the compost produced. Few are truly sustainable, thanks to an acceptable and stable quality of the compost and a certain number of customers.

Several pre-treatment and recycling facilities are available, especially to sort, pre-treat or stock recyclables. Few examples of complete recycling are also available, and mainly for some types of plastic. Other recyclables are sent to Israel for direct recycling. These activities are mainly informal, or formalized only after some steps of the recycling process.

\subsubsection{Solid waste recovery and recycling market}

Solid waste recycling initiatives in West Bank depend on one hand on the entrepreneurial capacity of individuals and, on the other hand, on the intervention of international organisations. The Palestinian regulatory framework, although it implements waste prevention, recovery and recycling activities (PNA, 1999; PNA, 2010), does not propose any incentives for the establishment of such initiatives. Neither does it provide environmental performance control systems for waste storing and treatment enterprises. The legislative framework, however, permits waste recycling enterprises to be registered in the chamber of commerce of the governorate in which they are situated, although with no obligations. The registration to the chambers of commerce, finally, does not imply any specific verification from the authorities. The specific political and social conditions of the area considered also have a non-negligible influence on the waste management sector (UNCTAD, 2014; World Bank, 2008). This limits the creation of large recycling enterprises and usually this activity is performed by small, family-run, individual business with a large participation of the informal sector.

The waste most traded is metal, which is collected throughout the West Bank. Metal waste is collected by itinerant waste buyers equipped with cars and megaphones who purchase materials directly from households before it enters into the formal solid waste management system. Metal waste collected by small-size buyers in the northern area is sold to larger-size industries and transported mainly to Ramallah or Eizarya. Then from the Haifa or Akka harbours it is shipped for international export. Although in minimum quantities, metal waste from the northern West Bank is also brought to Jericho, where an important local industry transports it to Jordan, where it is recycled. Metal waste collected in the Bethlehem and Hebron governorates, instead, is transported to a large industrial pole situated in the city of Idhna, in the south-west area of the Hebron governorate. From Idhna, metal waste is traded with Israeli buyers and, similarly for the Nablus area, it is brought to the Haifa and Akka harbours. In order to increase its value, metal waste is segregated manually by type. Frequently, metal waste is separated from plastic by fire, with negative consequences on the environment and human health.

Plastic waste is collected by several categories of stakeholders in the West Bank, and it is the only waste recycled in the territory. In the West Bank, in fact, several plastic waste recycling factories are distributed mainly in the north (Nablus) and in the south (Hebron). Such factories mainly recycle HDPE, PVC and PP with archaic and unsafe procedures. Waste usually is delivered to such industries mixed by type and colour, and as flakes. Thus the quality of the final products is expected to be low. PET is rarely collected, instead, as it is exclusively traded with Israeli industries, who implement waste producer responsibility policies for PET bottles. Plastic waste is mainly segregated by households and sold to middlemen, or collected by waste scavengers on dump sites. Due to the very low revenues achievable from the trade of such waste, large enterprises and JSCs do not invest in trading it.

Cardboard waste recovery is widespread mainly in the northern and central part of the West Bank. No cardboard recycling industries are available in the territory, and this waste is exclusively traded with Israeli buyers, who also establish the price of the material. Cardboard waste is collected by informal organised scavengers and through waste recovery initiatives developed by JSCs or municipalities in collaboration with private enterprises or local organisations. Cardboard waste is usually not compacted, as the revenues obtained by the trade would not cover the purchasing and running costs of waste balers. 
Only one material recovery facility is available. This facility is situated at Al Minya landfill and, at the moment, works at half of its treatment capacity $(150 \mathrm{t} / \mathrm{d}$ versus 300 $\mathrm{t} / \mathrm{d}$ capacity). The plant, equipped only with a trommel and a manual sorting line, mainly segregates cardboard. A second material recovery facility has been installed at the Zharat Al Finjan landfill (Jenin governorate) in 2012. The facility, managed through an agreement between private enterprises and public authorities, stopped its activities in 2014 due to political reasons. The plant, was equipped with a trommel, several manual sorting lines, shredders and balers.

Another waste recovery facility was installed by a private industry within a transfer station situated in the Nablus municipality. The plant, which was supposed to be run through a public-private partnership, never started its activities due to political and organisational reasons.

Other material recovery facilities are planned to be designed in the West Bank, and in particular within the area of the Jericho landfill and within the area of the Ramun landfill (which is still not constructed).

Organic waste treatment facilities, comprising only composting, are distributed throughout the West Bank territory, although there is a higher number in the Jenin governorate located north of the city. Existing facilities have been constructed and/or equipped through the economic support of international organisations. Two new composting plants are managed by local JSCs with the supervision of a Palestinian NGO (House of Water and Environment), and Jericho and Baytillu composting plants.

\subsubsection{Role of local and international organisations in im-} proving solid waste management

The West Bank region has enjoyed, currently as in the past, many interventions carried out by local and international organisations. Solid waste management projects, as well as studies on solid waste management systems, have been carried out with the scope of improving the environmental and sanitation performances of the territory. The majority of the interventions, however, failed due to the lack of a rigorous legislative framework, the scarce preparation of solid waste managers and lack of awareness in the population.

The NGO Nexus, in the years 2010/2011 tried to replicate Modena's separate waste collection method in a municipality of the Jenin governorate. The project had the main scope of segregating household food waste and composting it at a local cooperative, which, through the project, is equipped with machines for compost shredding and packaging. They also enjoyed several training sessions. The project, however, failed due to the lack of awareness of the households involved in the waste segregation project, who delivered very contaminated organic fractions, and due to the costs derived from material treatment. Similarly, between 2014 and 2017 Cesvi implemented a project in the north-west of the West Bank with the objective of diverting the organic market waste and the cardboard waste from final disposal and closing and remediating a municipal dump site. Through the project, with the collaboration of the University of Brescia, Cesvi successfully completed the remediation process of a dumpsite and strengthened the interest of the local JSC for the cardboard recycling programme, but failed in establishing a sustainable organic waste collection system. Commercial activities interrupted the segregation of organic waste as soon as the direct input from the NGO finished, and the local JSC did not pursue the objectives of the project.

JICA is a major organisation in the country, active in solid waste management projects, which, however, focuses its activities on the building capacity of local institutions and provision of solid waste management equipment. JICA, however, in its new operative strategy, is expecting to implement solid waste prevention, recovery and recycling programmes which also includes the population.

\subsection{Discussion}

Even though the per capita MSW generation was higher for the Region of Umbria, the amount of organic fraction generated was very similar for the two areas (about 180 $\mathrm{kg} /$ per capita/year) (Table 3). The number of specific facilities able to process this waste was practically absent in the West Bank. Only agricultural organic waste is currently composted in the entire West Bank territory through the static pile method. In some cases, especially, in Jenin, composting activities are performed only during the summer season. Nonetheless many initiatives have failed due to organisational problems and insufficient revenue for the farmers.

The number of mechanical sorting facilities per inhabitant able to manage unsorted waste was about ten times less for the West Bank compared to the Region of Umbria. Furthermore, the West Bank had a total absence of composting facilities. The lack of separated collection of the organic fraction is one of the main reasons, but also economic sustainability is another important aspect to be considered.

The MSWM fee payed by users, mainly citizens in the Region of Umbria was about $0.82 \%$ of the per capita GDP. For the West Bank area, this figure was higher, about 1.2\%. As reported by Al-Khatib et al. $(2010,2007)$ even though the incidence on the per capita GDP was higher, the fee was not enough to cover all the MSWM costs. This leads

TABLE 3: Comparison of the main indicators for the Region of Umbria and the West-Bank-Palestine.

\begin{tabular}{|c|c|c|}
\hline Indicator & Region of Umbria & West Bank \\
\hline MSW per kg/capita/year & 519 & 285 \\
\hline $\begin{array}{l}\text { Organic fraction kg/per capita/ } \\
\text { year }\end{array}$ & 180 & 178 \\
\hline MSWM fee/per capita GDP (\%) & 0.82 & 1.20 * \\
\hline $\begin{array}{l}\text { Mechanical treatment facilities } \\
\text { per } 10^{5} \text { inhabitants }\end{array}$ & 0.44 & 0.034 \\
\hline $\begin{array}{l}\text { Composting facilities per } 10^{5} \\
\text { inhabitants }\end{array}$ & 0.56 & 0 \\
\hline Recycling (\%) & $32^{a}$ & 6 \\
\hline Composting (\%) & $22.5^{\mathrm{a}}$ & 0 \\
\hline
\end{tabular}

* Estimated on the basis of Al-Khatib et al. (2010); a=at recycling/composting facility gate. 
to the absence of separated collection and of successive proper management and treatment phases as already described above.

The lack of infrastructures, financial support and political willingness leads the West Bank to a very limited percentage of recycled waste and to practically no composting of the organic fraction.

These results pointed out that the correct management of the organic fraction of MSW is a main challenge for the MSWM in the West Bank but, also that the current absence of an adequate funding program suggests the promotion of home composting or animal feeding recycling activities. Promotion of home composting can also be an effective approach for reducing and/or avoiding collection needs and related costs. This can also be an opportunity for the municipalities to use their budgets for improving the separation at source of other recyclables such as plastics and paper. In any case the success of such activities cannot be maximized without an adequate level of awareness of citizens and of decision makers together with a strong political willing. In particular, the weakness of this last aspect can frustrate all the initiatives promoted in this sector by international agencies and NGOs.

The percentage of recycling and composting in the Region of Umbria and reported in Table 2 was related to the amount of waste delivered at the recycling and composting plants. This means that these figures are not fully representative of the effective fraction of recycling and composting. The current system implemented for monitoring this aspect is not able to give adequate information about the recycling efficiencies for each region and for specific areas. Furthermore, national data (ISRPA, 2016) indicated that for some materials such as metals, glass and paper, the recycling efficiency of waste delivered to recycling facilities was up to $90 \%$, but for other materials such as plastics the recycling efficiency drops to less than $50 \%$. Similar considerations can also be made for the composting activity. In general, the amount of organic fertilizer (Table 1) generated after composting treatment can also be less than $15 \%$ of the amount of organic fraction at the facility inlet. This is a consequence of the processing loss (e.g. humidity and degraded organic matter), but also a consequence of the level of impurities that needs to be removed due to the low quality of the collection phase. All these considerations lead to future discussion about the effective sustainability of given MSWM practices currently implemented in the Region of Umbria and at the EU level.

\section{CONCLUSIONS}

Lack of adequate infrastructures, economic budget and citizen awareness are the main causes for the low level of efficiency of waste management in developing countries, especially in the West Bank. Furthermore, the absence of a fully implemented market for the recycling industry limits the investment and the interest of the private sector. The main results pointed out that the economic viability of a more efficient waste management approach for the West Bank is difficult to be pursued due to the already quite high incidence of the fees payed when compared to the per cap- ita GDP.

Due to the high incidence of the organic fraction on the whole amount of waste generated in the West Bank, the promotion of home composting and/or recycling via animal feeding seems to be the best recommendation. This can contribute significantly to improving waste management in this area. Both environmental/sanitary and economic benefits could be achieved by this practice. The reduction in the amount of waste to be collected can increase the budget of municipalities for improving the collection of other recyclable fractions. It is important to note that this goal is difficult to achieve without an adequate level of citizen awareness and political support.

Although there is a higher efficiency and reliable political, legal and economic supporting scheme in the Region of Umbria, some critical aspects related to its effective sustainability were detected. The high percentage of separated collection did not generally correspond to an effective high recycling rate, particularly for plastics and the organic fractiona. This opens the floor to a discussion about the level of effectiveness of current waste management practices in the Region of Umbria, in particular, and in the EU in general. The low efficiencies found for the effective recycling of some relevant waste materials in these areas suggests that other environmental and economically sound management schemes should be investigated.

\section{REFERENCES}

Al-Khatib, A., Arafat, H.A., Besheer, T., Shawahneh, H., Salahat, A., Eid, J., Ali, W. 2007. Trends and problems of solid waste management in developing countires: A case study in seven Palestinian districts. Waste Management 27,1910-1919.

Al-Khatib, A., Monou, M., Zahra A.S.F.A., Shaseen, H.Q., Kassinos, D. 2010. Solid waste characterization, quantification and management practices in developing countries. A case study: Nablus district - Palestine. Journal of Environmental Management 91,11311138.

ARIJ. 2015. Status of the Environment in the State of Palestine 2015. http://www.arij.org/files/arijadmin/2016/SOER_2015_final.pdf.

Caniato, M., Vaccari, M. 2014. How to assess solid waste management in armed conflicts? A new methodology applied to the Gaza Strip, Palestine. Waste Management and Research 32 (9), 908-917.

CEC. 1977. Second EC Environment Action Programme: Commission of the European Communities, Brussels.

Centanni, E. 2012. Map available in "Is Palestine Really a Country?". Political Geography Now, 6 December 2012. http://www.polgeonow. com/2012/12/is-palestine-really-country.html.

CIA. 2017. "The World FactBook. Middle East: West Bank". https:// www.cia.gov/library/publications/the-world-factbook/geos/ we.html.

$\operatorname{COM}(614)$. 2015. Communication from the Commission to the European Parliament, the Council, the European Economic and Social Committee and the Committee of regions - Closing the Loop - An EU Action plan for the Circular Economy. 2.12.2015, Brussel. Available at: http://eur-lex.europa.eu/resource.html?uri=cellar:8a8ef5e8-99a0-11e5-b3b7-01aa75ed71a1.0012.02/DOC_1\&format=PDF . accessed on 20.02.2017.

Couth, R., Trois, C. 2011. Waste management activities and carbon emissions in Africa. Waste Management 31,131-137.

Couth, R., Trois, C. 2012. Sustainable waste management in Africa through CDM projects. Waste Management 32,215-2125.

De Gioannis, G., Muntoni, A., Cappai, G., Milia, S., 2009. Landfill gas generation after Mechanical Biological Treatment of Municipal Solid Waste. Estimation of gas generation rate constants. Waste Management 29, 1026-1034.

Di Maria, F. 2012. Upgrading of a Mechanical Biological Treatment (MBT) plant with a Solid Anaerobic Digestion Batch: A Real Case Study. Waste Management \& Research, 30 (10): 1089-1094. 
Di Maria, F., Sordi, A., Micale, C. 2013a. Experimental and life cycle assessment analysis of gas emission from mechanically-biologically pretreated waste in a landfill with energy recovery. Waste Management 33, 2557-2567.

Di Maria, F., Gigliotti, G., Sordi, A., Micale, C., Zadra, C., Massaccesi, L. 2013. Hybrid solid anaerobic digestion batch: Biomethane production and mass recovery from the organic fraction of solid waste. Waste Management \& Research, 31, 869-873.

Di Maria, F., Micale, C. 2014. A holistic life cycle analysis of waste management scenarios at increasing source segregation intensity: The case of an Italian urban area. Waste Management 34:2382-2392.

Di Maria, F., Sordi, A., Cirulli, G., Gigliotti, G., Massaccesi, L., Cucina, M. 2014. Co-treatment of fruit and vegetable waste in sludge digesters. An analysis of the relationship among bio-methane generation, process stability and digestate phytotoxicity. Waste Management 34(?);1603-1608.

Di Maria, F., Micale, C., Morettini, E., Sisani, L., Damiano, R. 2015. Improvement of the management of residual waste in areas without thermal treatment facilities: A life cycle analysis of an Italian management district. Waste Management 44(?), 206-215.

Di Maria, F., Segoloni, E., Pezzolla, D. 2016. Solid anaerobic digestion batch of bio-waste as pre-treatment for improving amendment quality: The effect of inoculum recirculation. Waste Management 56,106-112.

Di Maria F, Sisani F. 2017. A life cycle assessment of conventional technologies for landfill leachate treatment. Environmental Technology \& Innovation, 8, 411-422

Di Maria F, Sisani F, Contini S, Ghosh SK. 2018. Impact of different schemes for treating landfill leachate. Waste Management 71,255266.

D. Lgs. 2010. Decreto Legislativo 29 aprile 2010, n.75. Riordino e revisione della disciplina in materia di fertilizzanti, a norma dell'articolo 13 della legge 7 luglio 2009, n. 88. Gazzetta Ufficiale n. 12126 Maggio 2010.

Guerrero, L.A., Maas, G., Hogland, W. 2013. Solid waste management challenges for cities in developing countries. Waste Management 33,220-232.

Henry, RK., Youngsheng, Z., Jun, D. 2006. Municipal solid waste management challenges in developing countries - Kenyan case study. Waste Management 26(?),92-100.

ISPRA. 2016. Rapporto Rifiuti Urbani. Edizione 2016. ISPRA, Rapporti 251/2016. ISBN 978-88-448-0791-7.

ISTAT. 2016. Available at: www.istat.it/it/umbria Accessed on 25.03.2017.
Komilis, D.P., Ham, R.K., Stegmann, R., 1999. The effect of Municipal Solid Waste pre-treatment on landfill behaviour: a literature review. Waste Management and Research 17, 10-19.

Kumar, S., Bhattacharyya, J.K., Vaidya, A.N., Chakrabarti, T., Devotta, S., Akolkar, A.B. 2009. Assessment of the status of municipal solid waste management in metro cities, state capitals, class I cities and class II towns in India: an insight. Waste Management 29,883-895.

Manaf, L.A., Samah, M.A.A., Zukki, N.I.M. 2009. Municipal solid waste management in Malaysia: Practices and challenges. Waste Management 29, 2902-2906.

Marshall, R.E., Farahbakhsh, K. 2013. Systems approach to integrated solid waste management in developing countries. Waste Management 33, 988-1003.

MoLG. 2010. National Strategy for Solid Waste Management 20102014. Available at: http://www.molg.pna.ps/studies/TheSolidWasteManagementStrategy2010-2014.pdf.

Morello, L., Cossu, R., Raga, R., Pivato, A., Lavagnolo, M.C. 2016. Recirculation of reverse osmosis concentrate in lab-scale anaerobic and aerobic landfill simulation reactors. Waste Management 56(?), 262-270.

PCBS. 2017. "Key Indicators". http://www.pcbs.gov.ps/site/lang_ en/881/default.aspx\#Population.

Smidt, E., Tintner, J., Bohm, K., Binner, E., 2011. Transformation of biogenic waste materials through anaerobic digestion and subsequent composting of residues - a case study. Dyn. Soil, Dyn. Plant 5, 63-69.

Tian, H., Gao, J., Hao, J., Lu, L., Zhu, C., Qiu, P. 2013. Atmospheric pollution problems and control proposal associated with solid waste management in China: A review. Journal of Hazardous Materials 252-253,142-154.

UN News Centre. 2011. „Ban sends Palestinian application for UN membership to Security Council“. http://www.un.org/apps/news/ story.asp?NewsID=39722\#.WT3AguuGPIV.

Zhang, D.Q., Tan, S.K., Gersberg, R.M. 2010. Municipal solid waste management in China: Status, problems and challenges. Journal of Environmental Management 91,1623-1633.

Palestinian National Authority, 1999. Palestinian Environmental Law.

Palestinian National Authority, 2010. National Strategy for Solid Waste Management in the Palestinian territory, 2010-2014.

UNCTAD, 2014. Palestinian fiscal revenue leakage to Israel under the Paris Protocol on Economic Relations. United Nations Conference on Trade and Development, volume, issue, page.

World Bank, 2008. An analysis of the economic restrictions confronting the West Bank and Gaza Available at: http://siteresources.worldbank.org/INTWESTBANKGAZA/Resources/EconomicrestrictionstSept.08.pdf. Retrieved on 13 June 2017. 